\title{
Presupposition towards Metadiscourse in Product Centric Malaysian Food \& Beverages Television Advertisements
}

Nur Widad Roslan, Hazlina Abdul Halim, Mohd Azidan Abdul Jabar and Hamisah Hassan

To Link this Article: http://dx.doi.org/10.6007/IJARBSS/v11-i3/8671

DOI:10.6007/IJARBSS/v11-i3/8671

Received: 09 January 2021, Revised: 03 February 2021, Accepted: 28 February 2021

Published Online: 15 March 2021

In-Text Citation: (Roslan et al., 2021)

To Cite this Article: Roslan, N. W., Halim, H. A., Jabar, M. A. A., \& Hassan, H. (2021). Presupposition towards Metadiscourse in Product Centric Malaysian Food \& Beverages Television Advertisements. International Journal of Academic Research in Business and Social Sciences, 11(3), 601-611.

\section{Copyright: (c) 2021 The Author(s)}

Published by Human Resource Management Academic Research Society (www.hrmars.com)

This article is published under the Creative Commons Attribution (CC BY 4.0) license. Anyone may reproduce, distribute, translate and create derivative works of this article (for both commercial and non-commercial purposes), subject to full attribution to the original publication and authors. The full terms of this license may be seen

at: http://creativecommons.org/licences/by/4.0/legalcode

\section{Vol. 11, No. 3, 2021, Pg. 601 - 611}

Full Terms \& Conditions of access and use can be found at http://hrmars.com/index.php/pages/detail/publication-ethics 


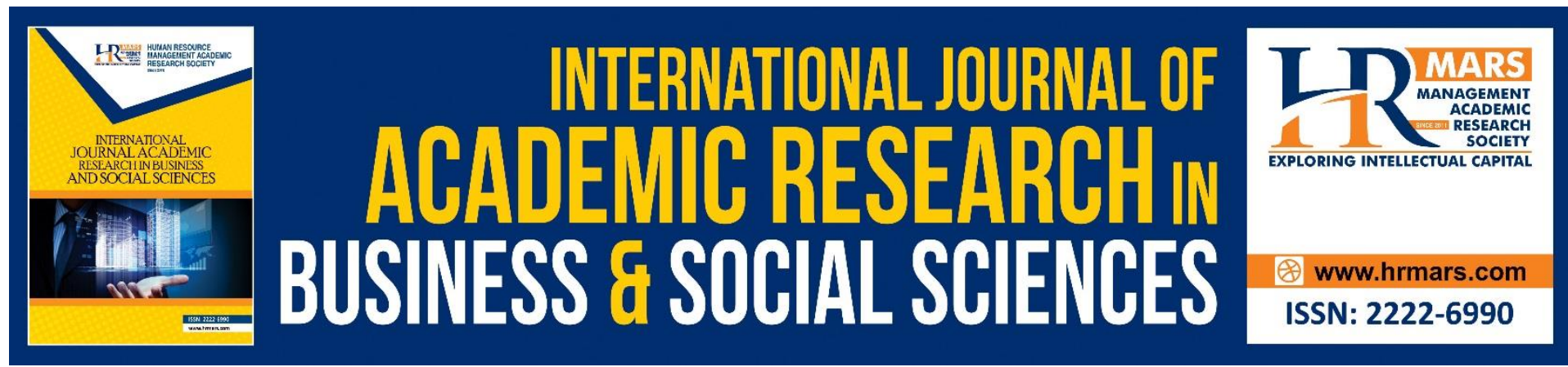

\title{
Presupposition towards Metadiscourse in Product Centric Malaysian Food \& Beverages Television Advertisements
}

\author{
Nur Widad Roslan, Hazlina Abdul Halim, Mohd Azidan Abdul \\ Jabar and Hamisah Hassan \\ Faculty of Modern Languages and Communication, University Putra Malaysia, Serdang, \\ 43400, Selangor, Malaysia \\ Email:widad.roslan@gmail.com, hazlina_ah@upm.edu.my, azid@upm.edu.my and
} hamisah@upm.edu.my

\begin{abstract}
The advertising industry has moved into the digital era, however it does not mean the traditional platform is not affective. Television advertisement is still the main advertising platforms that brands choose to advertise their product or services. This is because, television has a big reach and consumers presupposes that brands who advertise on television are well established, hence making it one of the factors brands still consider advertising on television. When it comes to advertising, the copy is indeed important in order to convey the message towards the consumers, in which metadiscourse plays a big role in shaping the contents of the advertisement. For this study, if focuses on the consumers presupposition towards the presence of metadiscourse in product centric Malaysian food and beverages television advertisement. The methods used are qualitative methods, where 30 Malaysian subjects chosen at random are show 10 Malaysian food and beverages television advertisement. The results shows that the consumers presupposes that metadiscourse helps them to understand the message of the advertisement better and how the target audience influences the use of metadiscourse in the content of the television advertisement. It is hoped further studies are done on metadiscourse for non-product centric television advertisements.
\end{abstract}

Keywords: Critical Discourse Analysis, Presupposition, Metadiscourse, Television Advertisement

\section{Introduction}

Television advertisement is one of the main mediums for brands to advertise their products and service. As mention by Modig \& Dahlen (2019), television advertisement is one of the mediums that play one of the most vital roles in communicating with the brands target audience, be it to inform about te product or to persuade the target audience to buy the products or services. Okpara \& Agu (2016) further explains how television advertisement is the bridge to link the brand with their audience. With this, it shows how many advertisements although moving towards a digital era still relies on television as one of the main mediums of advertising products or services (Lal \& Vats, 2016). Khairulwafi \& Ruslan Abdul Rahim (2017) had mentioned how Malaysia is known for its different races but still manage to harmonise 
together as the citizens if Malaysia. Referring to the statement, that is why food and beverages brand has the most universal language, which is food that everyone no matter the race enjoys. Within the food and beverages television advertisement, many consumers are not aware of the presence of metadiscourse, but it is metadiscourse that helps shape and outline the food and beverages storyline of the television advertisement.

\section{Literature Review}

Brands have many platforms where they can advertise their product for services, but many of the brands still considers television advertisement as their main platform to advertise their product and services. This is because, as mentioned by McMahon, Mann, Tuma \& Flyn (2018), television advertisement is one of the biggest platforms for brand to advertise during the rise of the advertising sector. Although most brands have switched to digital, but there is now even digital television, as they still adopt the concept of television but going online as well, because the advertising industry is still aware of the dominant influence television has towards their viewers. A study by Nur Widad Roslan, Hazlina Abdul Halim \& Mohd Azidan Abdul Jaabar (2018) agrees with McMahon, Mann, Tuma \& Flyn (2018) study, where Nur Widad Roslan, Hazlina Abdul Halim \& Mohd Azidan Abdul Jaabar (2018) had mentioned that television advertisement is still pioneering in the advertising industry as it still deemed as relevant and most impactful medium to advertise a product or a service. Other than that, Bellman, Nenycz-Thiel, Kennedy, Larguinat, McColl \& Varan (2017) study shows how television advertisement is able to influence the consumers purchasing intentions by understanding the consumers wants and needs and in cooperate it in the television advertisement and further influence the audience to further make their purchasing decision, with the help of highlighting the products benefits in the advertisement itself. Additionally, Bellman et al., (2017) further added that television advertisement mostly have a bigger reach as compared to other platforms and that consumers perceive a brand is established when has been advertised on television.

When it comes to television advertisement, the process of script writing is involved, or in advertising terms, the copy written by the copywriter. Kotler \& Keller (2016) study had mentioned that there are many different classifications when it comes to copywriting and that the copywriter's role is to be able to use the different classifications together with the correct discourse in order to develop a meaningful yet award winning advertisement. When it comes to writing for an advertisement, copywriter have an knowledge in the discourse that they need to use, depending on the brand and target audience that the advertisement is for, as well as the platform the advertisement will be advertised on. The most important part of using discourse in writing copy for the advertisement is using the correct discourse. But one of the most important discourse is metadiscourse. Metadiscourse helps the copywriters to further organize how they will be writing the storyline (Hyland, 1998). Additionally, Gee (2014) had defined discourse a sequence that is used by writer to connect sentences or even storyline with each other. Without metadiscourse, the flow of the television advertisement will be all over the place, and it will be hard for the audience to understand what the advertisement is trying to convey, when there is not correct metadiscourse. Bisoyi, Yadav \& Barua (2014) had mentioned in their study that the way a message is presented verbally through the advertisement can influence a consumer's presupposition towards the quality of the brand. Hence why, metadiscourse is very critical and needs to be present when creating copy for television advertisements. 
According to Younas, et al. (2015), his study had focused on social mobility and culture and how it has limited the consumers of their discourse ability because of the social resources that the Pakisatani is unable to get, hence their discourse knowledge is very limited. Similarly, Rafia Bila \& Wasima Shehzad (2019) study focused on the written discourse found on the public transport vehicles. The findings showed in-depth lexicalization as well as over using metaphors in order to convey the actual message which is the social and moral attributes of those who wrote such linguistics. This shows that, the knowledge on discourse depends on where and how we get the information as well as the resources that people are able to get in order to further improve their discourse knowledge. This relates on how audiences are what influences the use of discourse in television advertisement, because the advertisement wants to influence the audience, therefore the advertisement need to talk like the audience as well, for the audience to easily understand the message and can influence the audiences purchasing decision.

The objective of this study is to identify and analyse consumers' presupposition towards the presence if metadiscourse in product centric Malaysian Television Advertisement, in which will be analysed according to Fairclough (1995) critical discourse analysis, under the second dimension which is discourse practice analysis, in which involves two subcategories which is presupposition and metadiscourse.

\section{Methodology}

This study is using qualitative method. This is because, when it comes to critical discourse analysis, text needs to be analysed critically against the dimensions listed by Fairclough (1995), therefore a qualitative methods is most suitable. 30 subjects chosen at random are interviewed individually with 10 open ended questions. The subjects are first shown 10 Malaysian food and beverages television advertisement and are explained what metadiscourse is in order for them to better understand and know how to answer the interview questions that is in regards to metadiscourse in the food and beverages television advertisement content.

Food \& Beverages Television Advertisement Copy

A1 Product: Lipton Extra Kaw

Celebrity Endorser: Zul Arrifin \& Fathia Latiff 


\begin{tabular}{|c|c|}
\hline & $\begin{array}{l}\text { Copy: } \\
\text { Intan: Do you want me to make Tea for you? } \\
\text { Zul: Can } \\
\text { Intan: Firstly, pour the hot water. Then put in The lipton extra kaw. See Papa, it's } \\
\text { beautiful. } \\
\text { Zul: Thick and rich with tea flavor. Yoru Tea is definitely Kaw. Only your (kaw) for } \\
\text { me } \\
\text { Intan: Extra kaw for you }\end{array}$ \\
\hline $\mathrm{A} 2$ & $\begin{array}{l}\text { Product: Marigold Peel Fresh } \\
\text { Celebrity Endorser: Lisa Surihani } \\
\text { Copy: We all need } 2 \text { serving of fruits daily. But with today's busy lifestyle it's not } \\
\text { easy. Luckily there's marigold peel fresh. Rich with Vitamin A, C and E is the perfect } \\
\text { complement to your daily fruit goodness. That's why many Malaysian's and I trust } \\
\text { marigold [eel fresh for our daily fruit goodness. }\end{array}$ \\
\hline A3 & $\begin{array}{l}\text { Product: Yakult } \\
\text { Celebrity Endorser: Scha Alyahya \& Awal Ashaari } \\
\text { Copy: } \\
\text { Lara: Shirota } \\
\text { Scha: Contains } 30 \text { millions good bacteria Shirota strain for your guts. More than } 80 \\
\text { years of experience. Yakult for everyone everyday. } \\
\text { Yakult }\end{array}$ \\
\hline A4 & $\begin{array}{l}\text { Product: Nestle Crunch Wafer } \\
\text { Celebrity Endorser: Awal Ashaari } \\
\text { Copy: } \\
\text { Narrator: Are you ready for the crunch? } \\
\text { Awal: Hair straightener? } \\
\text { Narator: Nestle Crunch Wafer. So crunchy it will blow you away. Crunchiest wafer } \\
\text { in Malaysia. Can you handle the crunch? }\end{array}$ \\
\hline A5 & $\begin{array}{l}\text { Product: Kopiko L.A. Coffee } \\
\text { Celebrity Endorser: Aisha Sinclaire, Awal Ashaari, Scha Alyahya, Alvin Wong \& } \\
\text { Chelsia Ng } \\
\text { Copy: } \\
\text { Aishah: Kopiko L.A Coffee, the new coffee in Malaysia with less acid. } \\
\text { Alvin: True, less acid more comfortable for the stomach right? } \\
\text { Awal: It's easy, can be done at any time. But the most important is the aroma. If } \\
\text { you want to drink Kopiko L.A Coffee ice, use } 2 \text { packets, it taste more nice. } \\
\text { Alvin: Emm so nice, this is real coffee. } \\
\text { Chelsia: Back then, I didn't drink coffee often, but now I always drink kopiko L.A } \\
\text { coffee. No problem. } \\
\text { Scha: Back then I liked a different coffe. But now, I only drink kopiko L.A Coffee } \\
\text { Narratoe: Kopiko L.A Coffee, coffee with less acid formula new in Malaysia. } \\
\text { Chelsia: I even kept it in my bag. } 1 \text { day can drink } 3 \text { times. } \\
\text { Narrator: Kopiko L.A Coffee. The delicious coffee that does not effect the stomach. }\end{array}$ \\
\hline A6 & $\begin{array}{l}\text { Product: Heinz ABC Kicap Manis } \\
\text { Celebrity Endorser: Awal Ashaari \& Scha Al Yahya } \\
\text { Copy: } \\
\text { Daughter: What do we do? }\end{array}$ \\
\hline
\end{tabular}




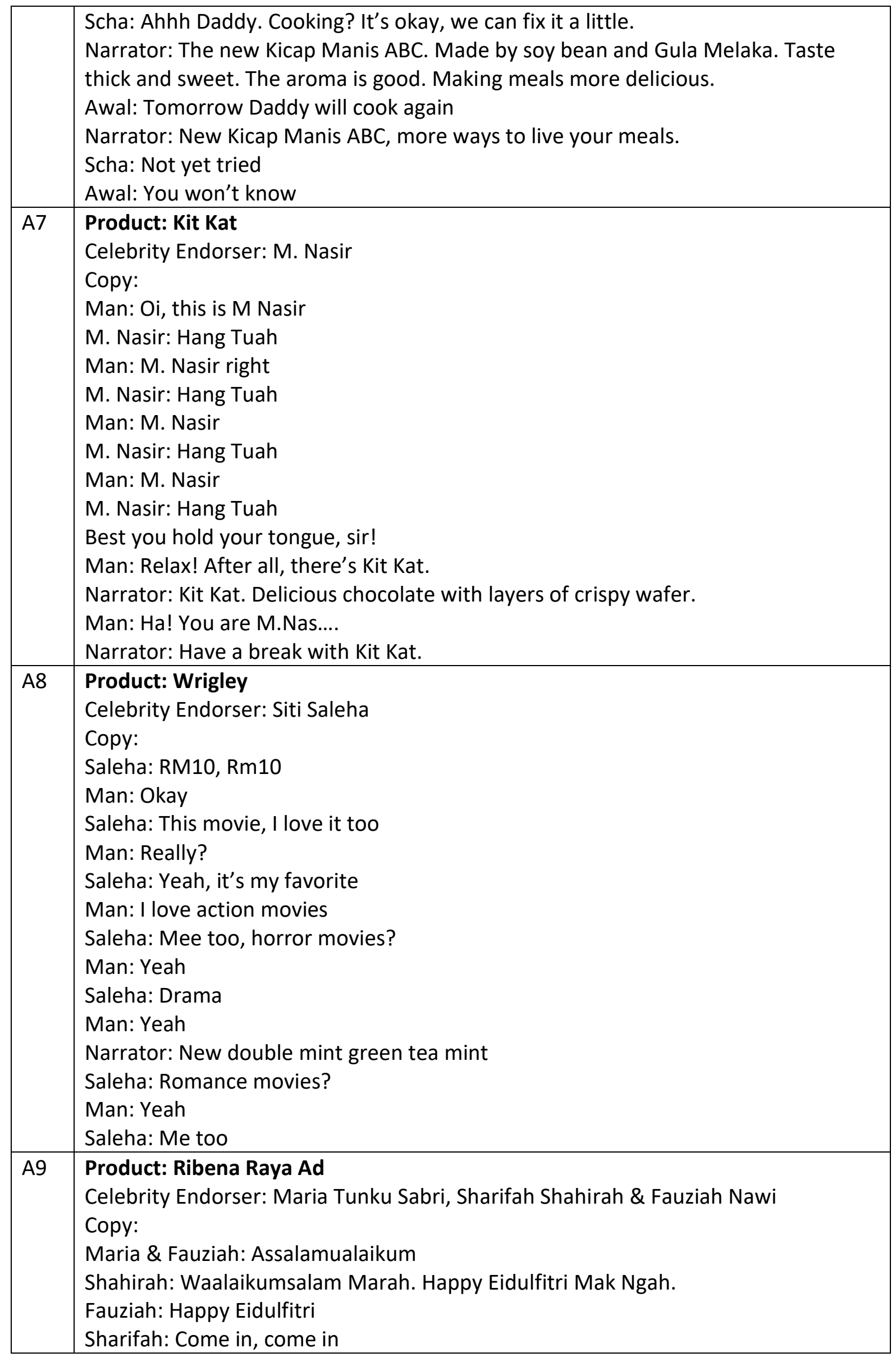




\begin{tabular}{|l|l|}
\hline & Fauziah: Her "Kuih" all normal \\
& Maria: It's okay \\
& Shahirah: Hold on ,I make water. \\
Maria: This time, it must be orange water. \\
Fauziah: Eidulfitri she won't serve RIBENA! \\
Maria \& Fauziah: Wahhh, you have class Shira \\
Kid: It's 100\% vitamin C for our daily lives.
\end{tabular}

\section{Results and Discussion}

Metadiscourse shapes the outline of the food and beverages television advertisement

Based on the findings, it shows that the presence of metadiscourse in food and beverages television advertisement is very important. Metadiscourse can be divided into two where the first is textual and second is interpersonal. For S1, she agrees that metadiscourse is important in an advertisement "I think metadiscourse is important in an advertisement", because advertisement does not work well without the copy, and without proper metadiscourse or organisation of the copy in an advertisement, then the meaning of the message may or may not be delivered to the target audience. In S1's case, she mentions the textual metadiscourse in an advertisement as the organisation of copy in an advertisement needs to be well written. She further elaborates that "television advertisement is more organised for viewers to understand especially for advertisements focusing on products, organisation is very important if not then it will be hard to understand the message". So when there is a textual metadiscourse in an advertisement, the advertisement is more well organised and that when it is well organised, the viewers will understand the advertisement better.

In an advertisement, the structure of the copy needs to be in a certain way according to how an advertiser wants to advertise the brand. Either they introduce the problem then the solution, or vice versa where they give the solution because there was a problem in the first place. S2 and S8 on the other hand is aware of metadiscourse in an advertisement and has a similar feeling as S1, where S2 and S8 feels that the structure and organisation of the copy in an advertisement needs to be in favour of the audience "The organisational structure of a person's opinion should be considered when doing a television advertisement" mentioned S2, S8 agreed and further added that when there is structure in product based advertisements, us audience will understand the storyline better. Just as how Batra \& Keller (2016) mentioned that advertisements need to understand the wants, needs, interest and goals of the audience.

In this case of metadiscourse in advertising, the opinion of the audience should be taken into consideration when developing the television advertisement. In Malaysian television advertisement, it can be seen how they have taken into consideration the metadiscourse of consumers and making sure sensitive topic like religion and race is not mentioned in an 
advertisement, especially in food and beverages category as it is a universal category as everyone needs food and beverages no matter the race and religion. Therefore, the organisation of the copy in the advertisement should be well thought of. Other than that, S8 further explains "This is because, if the understanding of a target audience structure of thinking is not understood by the audience, then the message of the advertisement can't be delivered properly".

Malaysian television advertisements are very serious in highlighting the metadiscourse in an advertisement to make sure the key message is delivered well to the audience as if the organisation of the copy is haywire and difficult to understand, then the message of the advertisement can be misinterpreted or misunderstood by viewer. In S8 point of view, without metadiscourse, audience will find it hard to understand the copy of the advertisement as there is no structure towards the message. Biber \& Gray (2013) in their study had mentioned how a written text always has a rule that most writers use to follow, for the native readers to understand. In $\mathrm{S} 8$ case, advertisement should have the metadiscourse element rule on the structure and how the copy written as mentioned by Biber \& Gray (2013). With this, advertisement will be neatly arranged in order for audiences to understand.

Target Audient influences metadiscourse in food and beverages television advertisement

If an advertisement does not have a good structure or metadiscourse in an advertisement, then it will be hard to understand by consumers, as S14 said "So if there is no good structure in an advertisement, then the advertisement will appear not interesting or the advertisement message not delivered to the audience". When an advertisement message is not delivered to the audience, then there is no point in developing an advertisement. Economic times (2017) mentioned how advertising is a communication method towards consumers for a brands product or services, so if the key message is not well delivered in an advertisement, then it is not an advertising method as it does not communicate what the brand wants. S14 also mentioned how the copywriter should understand the audience before developing the copy "Understanding the audience is one of the key aspects in trying to develop a good message in advertisements". A good message as mentioned by Kim \& Jay (2015) is when the consumers want to finish watching the advertisement and understands the message that is being delivered in the television advertisement. When audience understands the message being delivered in an advertisement, then it proves there is good structure in the advertisement. Besides that, S19 explains how a television advertisement copy should be well organised. He further elaborates how "Television advertisement must be organised according to a consumer's point of view, not a brand". A brand always wants to highlight their product features first and have the whole copy in the television advertisement about the product. The copy may be what the brand wants, but not what consumers want. An advertisement that has the metadiscourse elements is always highlighted or copy in a certain arrangement to follow the consumers' needs. As mentioned by S19, "organised towards a consumer's point of view, not the brand", where some consumers do not want to know the full features of the product in the advertisement as they can see it, but some consumers would rather want to know the problem that is related to the advertisement, and wants to know how the product is the solution to their problems. Stipp (2018) mentioned how advertisement should be a persuasive medium as it is paid medium, therefore to persuade consumers to buy the product or brand through watching the advertisement. So if the metadiscourse is all over the place in the advertisement, then some consumers would find it confusing and opt to go for a different brand that their advertisement highlights a better metadiscourse and provides the solution the consumers' problem. Just as how S19 perceived "As what brands want to portray are 
normally their product from the start until the end of the advertisement", with this in advertisements it is best to keep the structure within the metadiscourse organisational. S19 further elaborated "But in advertising perspective, it should be organised in a way of problem solution, or solution because of the problem", where with this advertisement should be organised by highlighting the problem then introducing the solution which is the product or service, or vice versa as mentioned by (Stipp, 2018; Belch \& Belch, 2013). Stipp, 2018; Belch \& Belch (2013) also mentioned this in their study where the message in an advertisement should be from both what the client wants to put in the advertisement and what consumers want to hear, that is where an effective way of delivering a message in an advertisement that covers both the client perspective of highlighting the product or services and the consumers perspective of wanting to know the solution to their problem.

Other than that, S26 opinion on metadiscourse in Malaysian television advertisement is that "In my opinion, metadiscourse is very important in developing a good advertisement". In order to come up with a good metadiscourse structure in an advertisement, normally copywriters need time to produce a good copy by making sure that they understand and deconstruct the brief, absorb the proposition, making the creative leap and coming up with the communication idea and the communication (Bisoyi, Barua \& Guha, 2013). A good advertisement as mentioned by Stipp (2018) is when the consumers understand the message and finished watching the television advertisement. So a good advertisement needs to blend together with the metadiscourse element for the copywriter to create a good copy to be delivered to the target audience. S26 further explains "With metadiscourse, some advertisement won't make any sense and that it will be just very boring and product heavy advertisement". She states without the metadiscourse element in the copy of the television advertisement, there is no proper structure and consumers would not understand, lose interest in watching an advertisement and especially if the advertisement of the product mentions heavy, then consumers will just stop viewing the advertisement as there is no specialty of the advertisement that wants to make the viewer keep on viewing the advertisement. Chang (2012) had mentioned in his study how copywriters need time to brain storm for ideas. With the present knowledge of the metadiscourse element, the copywriter can structurally arrange the idea by keeping into consideration the metadiscourse of the advertisement, the product owners as well as the consumers.

\section{Conclusion}

Based on the findings and discussion above, it shows that metadiscourse is an important element that needs to be present in a product related television advertisement. This is because, consumers presupposition towards metadiscourse is it helps shape and maintain the essential elements of a television advertisement which is the storyline. Without metadiscourse, consumers find it hard to understand an advertisement because it can be all over the place without the correct structure. Other than that, although this study focuses on food and beverages, the findings may be applicable for any product that uses television as their main medium to advertise their product. Metadiscourse helps to shape and give a clear outline and flow of the storyline being told in the product television On the other hand, based on the findings; it also shows that the audience plays a big role in influencing the metadiscourse used in creating copy for the television advertisement. This due to the fact it is the audience that has the biggest factor in buying the product, hence the audiences opinion matters. The findings showed how the consumers would most likely purchase a product if it most relatable for the audience. Additionally, the consumers also presuppose that when the 
metadiscourse is in favour of the audience, example that it is easy to understand for the chosen target audience, it will influence the audiences purchasing decision. Another fact is that, before actually creating a television advertisement, normally advertising agency will first do a background check on the brands target audience and understand the needs, wants and attitude of the target audience. Once the advertising agency is able to fully understand the target audience is when they are able to create a television advertisement to influence the said target audience. Hence how the target audience can influence the use of metadiscourse in the television advertisement, where is it placed, how it is placed and why such metadiscourse is used in the food and beverages television advertisement.

Overall, the consumers presupposition towards the metadiscourse used in food and beverages television advertisements show that they understand the storyline more when metadiscourse is used and that the metadiscourse varies according to the brand. Additionally, the consumers also presuppose that indeed the use of metadiscourse varies according to brand because it targets different audiences; hence audiences are big influences towards the use of metadiscourse in food and beverages television advertisement. It is hoped that future research can be done on the importance of metadiscourse for non-product focus television advertisement, to get a perception from a different theme as well as study how important the presence of metadiscourse is for television advertisement copy.

\section{Reference}

Belch, G. E., \& Belch, M. A. (2013). A content analysis study of the use of celebrity endorsers in magazine advertising. International Journal of Advertising. 32 (3), 369-89

Bellman, S., \& Nenycz-Thiel, M., Kennedy, R., Laurent, L., McColl, B., \& Varan, D. (2017) What Makes A Televidion Commercial Sell? Using Biometrics to Identify Successful Ads. Demonstrating Neuromeasures' Potential On 100 Mars Brand Ads with Single-Source Data. DOI: 10.2501/JAR-2016-051 Published 1 March 2017.

Biber, D., \& Gray, B. (2013). Discourse Characteristics of Writing and Speaking Task Types on the TOEFL IBT Test: A Lexico-Grammatical Analysis. ETS Research Report Series. i-128 doi:10.1002/j.2333-8504.2013.tb02311.x

Bisoyi, D., Yadav, P., Barua, U., (2014). 'Copywriting and the Creative Edge', World Academy of Science, Engineering and Technology, International Science Index, Humanities and Social Sciences, 1(4), 943.

Economic Times. (2017). Definition of "Advertising". Accessed 16.7.17. http://economictimes.indiatimes.com/definition/advertising

Fairclough, N. (1995) Critical Discourse Analysis. (London, Longman).

Hyland, K. (1998). Persuasion and context: The pragmatics of academic metadiscourse. Journal of Pragmatics, 30(4), pp.437-455. Hyland, K (2005). METADISCOURSE London: Continuum Hyland, K. (2017). Metadiscourse: What is it and where is it going?. Journal of Pragmatics, 113, pp.16-2.

Kim, J. (2007). Observe advertising effectiveness correctly and create ads right. Ad Information. 321, 88-93.

Kotler, P., and Keller, K. (2016). Marketing Management. 15th ed. Harlow: Pearson.

Lal, R., \& Vats, A. (2016). Advertising Effectiveness On Television And Attitude Of Youth. Ahead. International Journal of Recent Research Review, 1, 60-65.

McMahon, L., Mann, G., Tuma, S., \& Flyn, M. (2018). Turning tv advertising back on. https://www.accenture.com/_acnmedia/accenture/conversion- 
assets/dotcom/documents/global/pdf/dualpub_26/accenture-turning-tvadvertising-back-on-pov.pdf

Modig, E., \& Dahlen, M. (2019). Quantifying the Advertising-Creativity Assessments of Consumers Versus Advertising Professionals. Journal of Advertising Research. DOI: 10.2501/JAR-2019-009 Published 29 March 2019.

Roslan, N. W., Abdul Halim, H., \& Abdul Jabar, M. A. (2018). Discourse in Colgate Palmolive Television Advertisement Copy: Colgate Maximum Cavity Protection. Jurnal Kemanusiaan November Special Edition.

Okpara, G. S., \& Agu, G. A. (2016). IntermediateMarketing; Bridging the gap between foundational and special.

Bila, R., \& Shehzad, W. (2019). Discourse Analysis of Written Text on Pakistani Public Transport Vehicles. International Journal of English Linguistics. 9. 496. 10.5539/ijel.v9n1p496. 